\title{
IEDZIVIOTĀJU MIGRĀCIJAS IEZĪMES UN NOTEICOŠIE FAKTORI LATVIJAS REĢIONOS
}

\author{
Juris Krūmiṇš, Aleksandrs Dahs, Atis Bērziņš
}

Latvijas Universitāte, Biznesa vadības un ekonomikas fakultāte, e-pasts: Juris.Krumins@lu.Iv, Aleksandrs.Dahs@lu.Iv, Atis.Berzins@lu.lv

\begin{abstract}
Anotācija. Kopš valsts neatkarības atgūšanas 1991. gadā, Latvijas demogrāfiskā attīstība ir raksturojama ar ievērojamām atškirīiām starp valsts centrālo daḷu un perifērijas reǵioniem. Pašvaldību līmeņa statistiskie dati liecina, ka sociāli ekonomiskās atškiirības mēdz variēties atkarībā no pētāmā demogrāfiskā indikatora, kaut gan kopumā tie demonstrē līdzịgas telpiskās iezīmes un stabilu tieksmi uz diverǵenci. Demogrāfísko indikatoru grupā pieaugošu interesi piesaista iedzīvotāju iekšzemes un starptautiskās migrācijas procesu statistiskie rādītāji. Īpašu uzmanību šajā aspektā pelna nedeklarētā migrācija, kuru ir iespējams novērtēt, aprēķinot starpību starp deklarēto un faktisko iedzīvotāju skaitu. Izvērtējot ekonometrisko modeḷu rezultātus, autori analizē migrācijas procesu atškirīibas Latvijas pašvaldībās un galvenos migrāciju ietekmējošos faktorus. Modelēšanas rezultāti liecina, ka, pētot starpību starp deklarēto un faktisko
\end{abstract}


iedzīvotāju skaitu, ir jāṇem vērā nozīmīga modeḷa kḷūdas daḷa, kas ir pakḷauta telpiskai autokorelācijai. Tas norāda uz telpiski korelētu faktoru klātbūtni, kas spēj ietekmēt nereǵistrētās migrācijas procesu. 2016. gada iedzīvotāju aptaujas rezultātu analīze sniedz papildus ieskatu nedeklarētās migrācijas procesos reǵionos.

Atslēgas vārdi: cilvēka ǵeogrāfija, migrācija, telpiskā analīze.

\section{Ievads}

Latvijas demogrāfiskajai attīstībai ir raksturīga būtiska telpiska nevienlīdzība. Vislielākās atšķirības šai ziṇā pastāv starp valsts centrālo daḷu (galvenokārt Rīgas un Pierīgas teritorijas) un perifēriju (pierobežas un piejūras pašvaldībām). Lai gan šīs atškirīibas lielā mērā nosaka arī lietotie demogrāfiskie indikatori, tomēr kopumā tām piemīt līdzịgas telpiskās izplatības iezīmes un stabila tieksme uz diverǵenci. Kopš Latvijas iestāšanās Eiropas Savienībā pastiprināta pētnieku interese tika pievērsta iedzīvotāju iekšzemes un starptautiskās migrācijas procesiem un ar tiem saistītām sociāli ekonomiskām problēmām (piem., Eglīte 2008). Arī 2011. gada tautas skaitīšanas rezultāti apstiprināja nozīmīgu emigrācijas lomu valsts un tās reǵionu depopulācijas norisēs. Tie akcentēja nepieciešamību labāk izprast nedeklarētās migrācijas apjomu, ko iespējams novērtēt kā starpību starp deklarēto un faktisko iedzīvotāju skaitu pašvaldībās.

Šì pētījuma mērḳis ir ar ekonometrisko modeḷu palīdzību analizēt galvenos migrāciju ietekmējošos faktorus reǵionālā aspektā un spriest par migrācijas procesu telpiskām iezīmēm. Modelēšanas rezultāti parāda, ka, pētot starpību starp deklarēto un faktisko iedzīvotāju skaitu, ir jāṇem vērā nozīmīga modeḷa kḷūdas daḷa, kas ir pakḷauta telpiskai autokorelācijai. Tas norāda uz nezināmu telpiski korelētu faktoru klātbūtni, kas spēj ievērojami ietekmēt iedz̄̄votāju izvēli attiecībā uz nereǵistrēto migrāciju.

Aptaujas rezultāti l̦auj secināt, ka Latvijas reǵionu iedzīvotāju migrācija ir komplekss process, kas veidojas un mainās gan sociāli ekonomisku faktoru, gan vides apstākḷu ietekmē.

\section{Dati un izpētes metodes}

2011. gada tautas skaitīšanas rezultāti sniedz pētniekiem detalizētus datus par demogrāfisko situāciju un tās pārmaiņām valstī un tās reǵionos (CSP 2012). Šie rezultāti arī apstiprināja Mihaila Hazana un Kaia Filipsa jau iepriekš paustās bažas par zemu novērtēto emigrācijas apjomu gan Latvijā kopumā, gan tās reǵionos (Hazans, Philips 2010). Konstatētā starpība starp faktisko iedzīvotāju skaitu (saskaṇā ar CSP aprēkiniem) un deklarēto iedzīvotāju skaitu (pēc PMLP datiem) parādīja patieso nedeklarētās iedzīvotāju emigrācijas apjomu un rosināja iedzīvotāju skaita novērtēšanas statistisko metožu precizēšanu. Drīz pēc tautas skaitīšanas rezultātu publicēšanas Valsts reǵionālās attīstības aǵentūra aprēḳināja jaunu regiionālo demogrāfisko indikatoru "atškirirība starp PMLP un CSP datiem" (VRAA 2013) (1. attēls).

Tomēr turpmākajos gados šim indikatoram un ar tā lietošanu saistītām problēmām netika pievērsta pietiekama pētnieku uzmanība. 


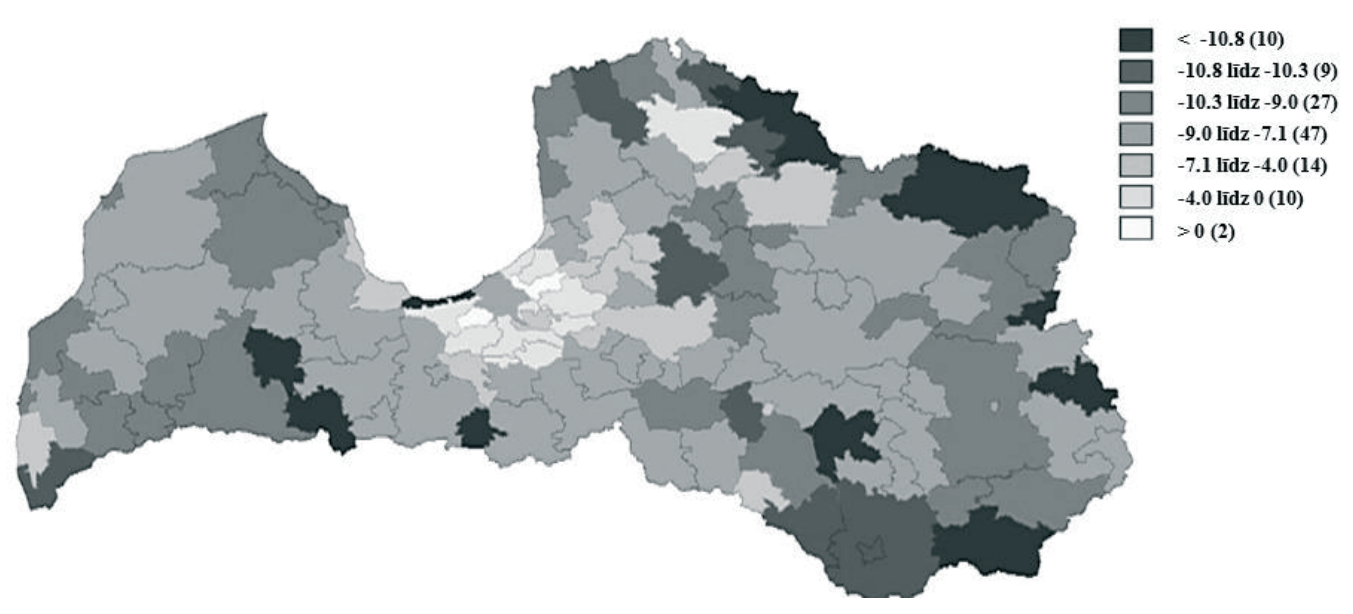

1. attēls. Atšķirīiba starp PMLP un CSP iedzīvotāju skaita datiem 2013. gadā (\%). Avots: Autoru izstrāde, izmantojot CSP un PMLP datus

Salīdzinājumā ar nedeklarētās migrācijas apjomu (ko ir iespējams netieši novērtēt, aplūkojot jau minēto atšķirību starp PMLP un CSP iedzīvotāju skaita datiem) deklarētās migrācijas apmērs (pēc PMLP Iedzīvotāju reg̣istra datiem) Latvijas pašvaldībās pēdējos gados ir bijis visai neliels (2. attēls), bet uzrādīja nedaudz atšḳirīgu telpisko struktūru. Tas ḷauj spriest par abu minēto procesu atšḳirīgām iezīmēm un ietekmes faktoriem.

Migrācijas procesu analīzei nepieciešamo neatkarīgo main̄̄go skaits ir ierobežots. To nosaka statistisko datu pieejamība pašvaldību līmenī. Analīzē izmantotie sociāli ekonomiskie indikatori ir ņemti no Teritoriālās attīstības un plānošanas informācijas sistēmas Reǵionālās attīstības indikatoru moduḷa (turpmāk - RAIM), kas apkopo un uzkrāj statistisko informāciju par teritoriālajām vien̄̄bām.

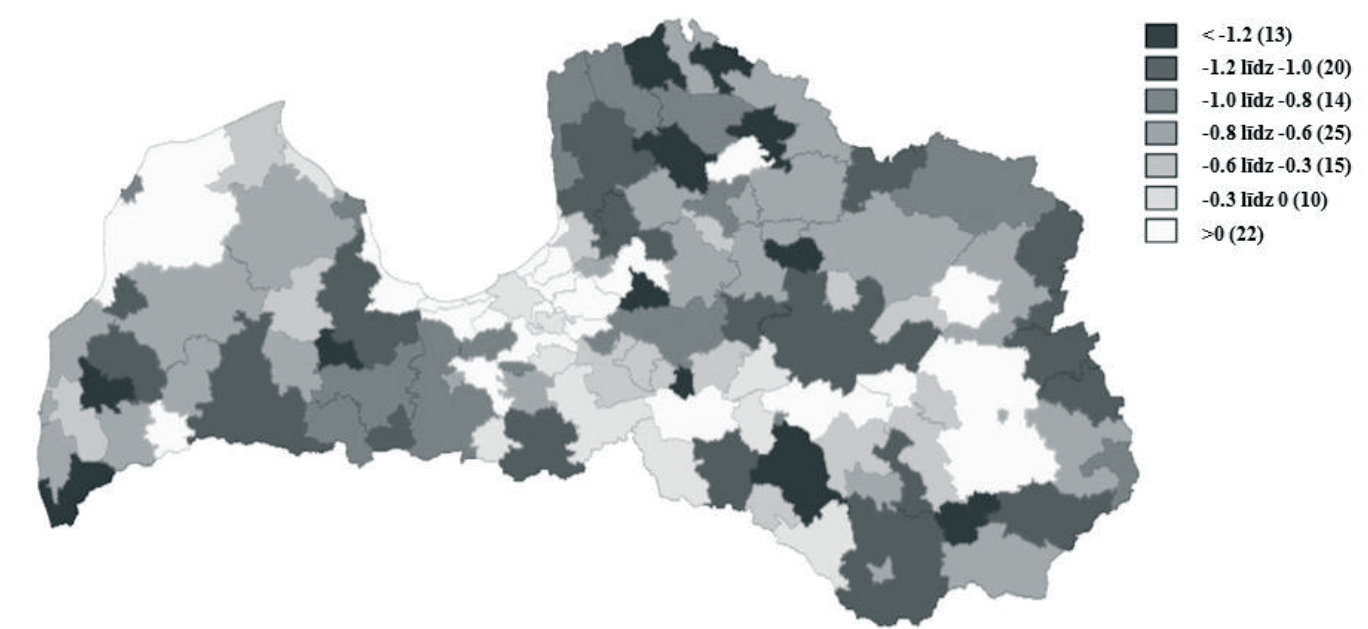

2. attēls. Iedzīvotāju skaita pārmaiņas deklarētās migrācijas rezultātā 2013. gadā (\%). Avots: Autoru izstrāde, izmantojot CSP un PMLP datus

N̦emot vērā, ka Latvijas pašvald̄̄bām ir raksturīga demogrāfisko procesu telpiskā autokorelācija (Dahs 2016), klasisko lineāro modeḷu pielietošana nav efektīva un nesniedz pietiekami detalizētu informāciju par migrācijas procesu norisi (Krejnikova 2013). Lai izpētītu deklarētās un nedeklarētās migrācijas ietekmes faktorus, ņemot vērā 
arī telpiskās dimensijas lomu, autori izvērtē gan klasiskā Lineārās regresijas modeḷa (LM), gan Telpiskās kḷūdas modeḷa (Spatial error model (SEM)) rezultātus. SEM modeḷa pielietošana l̦auj novērtēt ārējo faktoru telpisko ietekmi, papildus iekḷaujot telpiski svērtās kḷūdas neatkarīgu parametru vienādojuma labajā pusē (LeSage 1997). Tā kā tiem piemīt spēja attēlot telpiskās struktūras ietekmi uz pētāmajiem procesiem, telpiskie modeḷi arvien biežāk tiek pielietoti migrācijas procesu izpētē reǵionālajā līmen̄i (Lewandowska-Gwarda 2014 vai Scardaccione et al 2010).

Apzinoties ekonometriskās analīzes ierobežojumus, kā arī, ņemot vērā ierobežoto pieejamo ietekmes faktoru skaitu, kvantitatīvo analīzi papildina 2016. gada Latvijas iedzīvotāju aptaujas rezultātu analīze, kas sniedz arī papildus informāciju par nedeklarētās migrācijas procesiem pašvaldībās. Minētā aptauja tika veikta Valsts pētījumu programmas EKOSOC-LV 5.2.4 projektā 2016. gada sākumā visos Latvijas regíionos, lai uzzinātu iedzīvotāju viedokli par migrācijas un iedzīvotāju ataudzes jautājumiem. Pavisam tika aptaujāti 2049 Latvijas pastāvīgie iedzīvotāji (R̄̄gā 667, Pierīgā 357, Kurzemē 281, Zemgalē 235, Vidzemē 208 un Latgalē 301 respondents). Izlases aptaujas dati tika svērti, lai atbilstu CSP aprēķinātajam Latvijas reǵionu iedzīvotāju sastāvam pēc dzimuma, vecuma un tautības.

\section{Ekonometriskās analīzes rezultāti}

Lineārā modeḷa un Telpiskās kḷūdas modeḷa aprēḳinu rezultāti attiecībā uz migrācijas pārmaiṇu indikatoriem un dažiem to ietekmes faktoriem doti 1. tabulā.

1. tabula. Sociāli ekonomisko faktoru ietekme uz reǵionālajiem migrācijas indikatoriem Latvijā 2009.-2013. gadā (LM un SEM rezultāti)

\begin{tabular}{|c|c|c|c|c|}
\hline \multirow[b]{2}{*}{ Parametri } & \multicolumn{2}{|c|}{ Lineārais modelis (LM) } & \multicolumn{2}{|c|}{$\begin{array}{c}\text { Telpiskās kḷūdas modelis } \\
\text { (SEM) }\end{array}$} \\
\hline & \begin{tabular}{|c|} 
Starpības starp PMLP \\
un CSP iedzīvotāju \\
skaita datiem izmaiṇas \\
$(\%)$
\end{tabular} & $\begin{array}{c}\text { Deklarētās migrācijas } \\
\text { izmaiņas (\%) }\end{array}$ & \begin{tabular}{|c|} 
Starpības starp PMLP \\
un CSP iedzīvotāju \\
skaita datiem izmaiṇas \\
$(\%)$
\end{tabular} & $\begin{array}{c}\text { Deklarētās migrācijas } \\
\text { izmaiņas (\%) }\end{array}$ \\
\hline $\begin{array}{l}\text { ES struktūrfondi un } \\
\text { kohēzijas fondi (EUR) uz } \\
1 \text { iedzīvotāju }\end{array}$ & $-0.00215 *$ & $0.00036 *$ & $-0.00219 * *$ & $0.00036 *$ \\
\hline $\begin{array}{l}\text { Citi ES fondi (EUR) uz } 1 \\
\text { iedzīvotāju }\end{array}$ & 0.00065 & 0.00015 & 0.00088 & 0.00016 \\
\hline $\begin{array}{l}\bar{A} r v a l s t u \text { tiešās } \\
\text { investīcijas uz } 1 \\
\text { iedzīvotāju }\end{array}$ & 0.00012 & -0.00006 & 0.00021 & -0.00006 \\
\hline $\begin{array}{l}\text { Pašvaldību izdevumi } \\
\text { sociālajam atbalstam uz } 1 \\
\text { iedzīvotāju }\end{array}$ & 0.01203 & $-0.00556 *$ & 0.00540 & $-0.00584 *$ \\
\hline $\begin{array}{l}\text { Pašvaldības iekasētais } \\
\text { IIN uz } 1 \text { iedzīvotāju }\end{array}$ & -0.00147 & $0.00179 * * *$ & -0.00164 & $0.00180 * * *$ \\
\hline Bezdarba līmenis & 0.02783 & $-0.02615 * *$ & 0.01880 & $-0.02679 * *$ \\
\hline$\lambda$ (telpiski korelēta kḷūda) & - & - & $0.36608 * *$ & 0.08630 \\
\hline
\end{tabular}


Abi modeli parāda lielu iekasētā iedzīvotāju ienākuma nodokḷa (IIN) uz vienu iedzīvotāju un bezdarba līmeṇa ietekmi uz deklarētās migrācijas pārmaiṇām novados. Tāpat ir pozitīva ES Struktūrfondu un Kohēzijas fonda ieguldījumu ietekme uz abiem rezultatīvajiem rādītājiem. Šādu ieguldījumu rezultāti (uzlaboti sabiedriskie pakalpojumi, publiskā infrastruktūra u.c.) sniedz vislielāko labumu iedzīvotājiem, kas faktiski dzīvo noteiktā novadā vai tā tiešā apkārtnē (Bell et al. 2015).

Specializēts Telpiskās kḷūdas modelis parāda, ka, pētot starpību starp CSP un PMLP iedzīvotāju skaita datiem, ir jāṇem vērā nozīmīga modeḷa kḷūdas daḷa, kas ir pakḷauta telpiskai autokorelācijai. Šāds rezultāts norāda uz noteiktu telpiski korelētu faktoru klātbūtni, kas spēj ievērojami ietekmēt iedz̄ivotāju lēmumus par nedeklarēto migrāciju.

\section{Iedzīvotāju aptaujas rezultātu interpretācija}

Lai iegūtu papildu informāciju par nedeklarētās migrācijas iezīmēm un apjomu, autori analizē 2016. gada iedzīvotāju aptaujas rezultātus. Īpaša uzmanība pievērsta respondentu atbildēm uz jautājumiem, kas saistîti ar migrācijas faktoriem (2. tabula).

Aptaujas rezultāti liecina, ka dažādu pilsētu un novadu iedzìvotājiem, kuri plāno mainīt dzīvesvietu, ir gan kop̄ọi, gan atšķirīgi viedokḷi. Latvijas mazpilsētu un lauku teritoriju iedzīvotāji biežāk minēja dzīvesvietas maiņas iemeslus "darbs", "mācības" un "ǵimenes apstāklị”. Lauku teritoriju iedzīvotāju migrācijas lēmumus lielā mērā ietekmē arī "pakalpojumu pieejamība" un "atrašanās vieta", kas atbalsta ekonometriskās modelēšanas secinājumu par pozitīvu ES Struktūrfondu un Kohēzijas fonda ieguldījumu ietekmi uz migrācijas dinamiku.

2. tabula. Iedzīvotāju atbildes uz jautājumu: "Kādi ir galvenie iemesli, kāpēc plānojat pārcelties uz citu dzīvesvietu?" (pieḷaujamas ne vairāk kā trīs viena respondenta atbildes)

\begin{tabular}{|c|c|c|c|c|c|c|c|c|c|c|c|c|c|c|}
\hline \multirow{2}{*}{\multicolumn{2}{|c|}{ Intervijas vieta }} & \multicolumn{13}{|c|}{ Faktori } \\
\hline & & 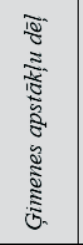 & 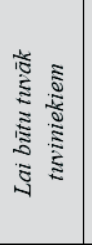 & 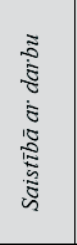 & 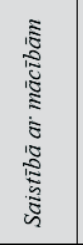 & 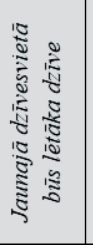 & 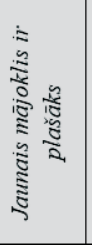 & 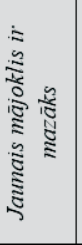 & 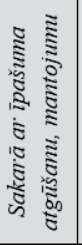 & 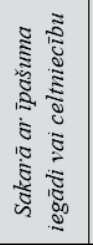 & 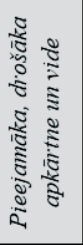 & 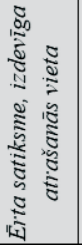 & 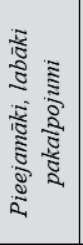 & 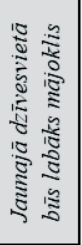 \\
\hline \multirow{7}{*}{ 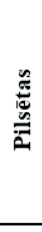 } & Rīga & $21.6 \%$ & $10.1 \%$ & $24.6 \%$ & $6.4 \%$ & $5.4 \%$ & $16.8 \%$ & $2.9 \%$ & $0.0 \%$ & $7.7 \%$ & $10.9 \%$ & $2.1 \%$ & $6.5 \%$ & $8.8 \%$ \\
\hline & Jelgava & $0.0 \%$ & $0.0 \%$ & $0.0 \%$ & $0.0 \%$ & $0.0 \%$ & $100.0 \%$ & $0.0 \%$ & $0.0 \%$ & $100.0 \%$ & $0.0 \%$ & $0.0 \%$ & $0.0 \%$ & $0.0 \%$ \\
\hline & Jūrmala & $0.0 \%$ & $0.0 \%$ & $0.0 \%$ & $0.0 \%$ & $100.0 \%$ & $0.0 \%$ & $0.0 \%$ & $0.0 \%$ & $0.0 \%$ & $0.0 \%$ & $0.0 \%$ & $0.0 \%$ & $0.0 \%$ \\
\hline & Liepāja & $10.3 \%$ & $13.6 \%$ & $36.1 \%$ & $0.0 \%$ & $0.0 \%$ & $24.7 \%$ & $0.0 \%$ & $11.2 \%$ & $10.8 \%$ & $12.1 \%$ & $0.0 \%$ & $0.0 \%$ & $0.0 \%$ \\
\hline & Rēzekne & $0.0 \%$ & $0.0 \%$ & $0.0 \%$ & $0.0 \%$ & $0.0 \%$ & $0.0 \%$ & $0.0 \%$ & $0.0 \%$ & $0.0 \%$ & $0.0 \%$ & $0.0 \%$ & $0.0 \%$ & $0.0 \%$ \\
\hline & Valmiera & $0.0 \%$ & $0.0 \%$ & $0.0 \%$ & $0.0 \%$ & $0.0 \%$ & $50.7 \%$ & $0.0 \%$ & $0.0 \%$ & $0.0 \%$ & $0.0 \%$ & $0.0 \%$ & $0.0 \%$ & $0.0 \%$ \\
\hline & Cita pilsēta & $12.9 \%$ & $0.0 \%$ & $48.4 \%$ & $20.8 \%$ & $4.1 \%$ & $13.5 \%$ & $3.6 \%$ & $0.0 \%$ & $10.6 \%$ & $0.0 \%$ & $11.2 \%$ & $8.5 \%$ & $12.1 \%$ \\
\hline \multirow{5}{*}{ 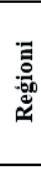 } & Pierīga & $22.2 \%$ & $3.1 \%$ & $36.2 \%$ & $26.3 \%$ & $6.6 \%$ & $12.9 \%$ & $3.5 \%$ & $0.0 \%$ & $10.0 \%$ & $0.0 \%$ & $12.7 \%$ & $2.0 \%$ & $9.9 \%$ \\
\hline & Vidzeme & $17.6 \%$ & $0.0 \%$ & $55.3 \%$ & $30.3 \%$ & $0.0 \%$ & $20.3 \%$ & $0.0 \%$ & $4.7 \%$ & $5.7 \%$ & $0.0 \%$ & $0.0 \%$ & $38.9 \%$ & $12.1 \%$ \\
\hline & Kurzeme & $9.5 \%$ & $12.4 \%$ & $41.6 \%$ & $0.0 \%$ & $0.0 \%$ & $22.5 \%$ & $0.0 \%$ & $10.2 \%$ & $9.9 \%$ & $11.1 \%$ & $0.0 \%$ & $0.0 \%$ & $0.0 \%$ \\
\hline & Zemgale & $25.7 \%$ & $6.5 \%$ & $43.4 \%$ & $23.0 \%$ & $0.0 \%$ & $15.7 \%$ & $0.0 \%$ & $0.0 \%$ & $20.9 \%$ & $0.0 \%$ & $0.0 \%$ & $19.5 \%$ & $0.0 \%$ \\
\hline & Latgale & $8.5 \%$ & $8.4 \%$ & $36.8 \%$ & $22.7 \%$ & $28.9 \%$ & $3.9 \%$ & $0.0 \%$ & $0.0 \%$ & $23.5 \%$ & $3.9 \%$ & $45.7 \%$ & $11.8 \%$ & $20.1 \%$ \\
\hline \multicolumn{2}{|c|}{ Lauku novadi } & $24.8 \%$ & $6.3 \%$ & $46.2 \%$ & $32.7 \%$ & $8.9 \%$ & $11.0 \%$ & $0.0 \%$ & $2.5 \%$ & $13.4 \%$ & $1.2 \%$ & $15.4 \%$ & $24.6 \%$ & $11.4 \%$ \\
\hline \multicolumn{2}{|c|}{ Latvijā kopā } & $19.1 \%$ & $6.4 \%$ & $36.8 \%$ & $17.7 \%$ & $6.3 \%$ & $15.5 \%$ & $1.8 \%$ & $1.6 \%$ & $10.8 \%$ & $4.9 \%$ & $8.3 \%$ & $12.4 \%$ & $9.4 \%$ \\
\hline
\end{tabular}

Avots: Ar 2016. gada EKOSOC-LV iedzīvotāju aptaujas rezultātiem pamatoti autoru aprēkinini 
Analizējot datus reǵionu griezumā, var saskatīt, ka darbs ir vissvarīgākais faktors, kas var mudināt iedzīvotājus mainīt dzīvesvietu. Interesantākus rezultātus sniedz arī atsevišķiem reǵioniem raksturīgu faktoru izpēte. Piemēram, Vidzemes iedzīvotājus interesē lielāka pakalpojumu pieejamība, savukārt Latgales iedzīvotājus satrauc satiksme un sasniedzamība, kas parāda šo reǵionu iedzīvotāju specifiskos izaicinājumus migrācijas kontekstā. Šo faktoru klātbūtne daḷēji izskaidro SEM modeḷa rezultātus attiecībā uz nezināmu un telpiski korelētu nedeklarētās migrācijas faktoru klātbūtni.

Laika periodā kopš Latvijas pievienošanās ES darba meklējumos ārvalstīs visbiežāk devušies mazpilsētu (12.1\%) un lauku teritoriju (11.4\%) iemītnieki. Trešo vietu šajā sarakstā ieņem rīdzinieki (8.8\%).

\section{Secinājumi}

Ekonomiskajiem faktoriem - nodarbinātības un ienākumu līmenim ir svarīga loma migrācijas procesos. Pastāv pozitīva ES Struktūrfondu un Kohēzijas fonda ieguldījumu ietekme uz deklarēto un nedeklarēto migrāciju, ko netieši apstiprina arī iedzīvotāju aptaujas rezultāti. Mazpilsētu un lauku teritoriju iedzīvotāju izvēli attiecībā uz migrāciju lielā mēra ietekmē arī tādi faktori kā mācības un gimenes apstākḷi.

Nedeklarētas migrācijas izpētē izmantotā telpiskā modeḷa rezultāti liecina par nezināma ietekmes faktora (vai faktoru) klātbūtni ar ḷoti augstu telpiskās korelācijas līmeni. Šo situāciju vismaz daḷēji var izskaidrot ar aptaujas rezultātos identificētu kvalitatīvu faktoru klātbūtni. Piemēram, atsevišķu reǵionu iedzīvotāju migrācijas procesos liela nozīme ir pakalpojumu pieejamībai vai satiksmei un sasniedzamībai.

Papildus konstatēts, ka mazpilsētu un lauku teritoriju iedzīvotāji ir biežāk uzturējušies ārvalstīs saistībā ar darba jautājumiem.

\section{Literatūras saraksts}

Bell, M., Charles-Edwards, E., Ueffing, P., Stillwell, J., Kupiszewski, M., Kupiszewska, D. (2015). Internal migration and development: comparing migration intensities around the world. Population and Development Review, 41(1), 33 - 58.

Centrālā statistikas pārvalde (2011). gada tautas skaitīšanas rezultāti: http://www.csb.gov.lv/statistikas-temas/tautas-skaitisana-28290.html (18.01.2018)

Dahs, A. (2016). Demographic Implications of the 2007-2013 Regional and cohesion policy Actions in Latvia. In: Bachtler J., Berkowitz P., Hardy S. \& Muravska T. (eds.) EU cohesion policy: Reassessing performance and direction. Regions and Cities book series. Routledge: London, 101 - 112.

Eglīte, P. (2008). Nedeklarētās izceḷošanas sekas un to rosinātā rīcība. Darbaspējīgo skaita mazināšanās Latvijā un iespējamie risinājumi. Apcerējumi par Latvijas iedzīvotājiem 13. Rīga: LZA Ekonomikas institūts, $16-24$.

Hazans, M., Philips, K. (2010). The Post-Enlargement Migration Experience in the Baltic Labor Markets. Kahanec, M. and Zimmermann, K. F. (eds.), EU Labor Markets After Post-Enlargement Migration, Berlin: Springer, 255 - 304.

Krejnikova, L. (2013). Spatial analysis of current migration differentiation of municipalities in Czech Republic. AD ALTA: Journal of Interdisciplinary Research, 3(1), 134 - 136.

LeSage, J. P. (1997). Regression analysis of spatial data. Journal of Regional Analysis and Policy, $27,83-94$.

Lewandowska-Gwarda, K. (2014). Spatial analysis of foreign migration in Poland in 2012 using geographically weighted regression. Comparative Economic Research, 17(4), 137 - 154. 
Reǵionālās attīstības indikatoru modulis [RAIM]: http://raim.gov.lv (15.01.2018)

Scardaccione, G., Scorza, F., Las Casas, G., Murgante, B. (2010). Spatial autocorrelation analysis for the evaluation of migration flows: the Italian case. Computational Science and Its Applications - ICCSA 2010. International Conference, Fukuoka, Japan, March 23-26, 2010, Conference proceedings, Part I, 62 - 76.

\section{Summary}

Since the restoration of independence in 1991, spatial demographic development in Latvia has been characterised by a widening core (central area of the country: capital city Riga and Pieriga region) and periphery (surrounding regions and counties) gap. Regional municipal statistics testify that observed demographic dichotomy differs by indicator used, but is consistent in terms of spatial distribution and demonstrates stable deviating trends. Among the most interesting and significant are the indicators associated with internal and external migration. Attention is drawn to the constructed indicator "missing declared population" (difference between declared or registered and factually estimated population number, hereafter - MDP), which to the large extent illustrates the volume of undeclared migration in the regions. By reviewing results of the relevant econometric models, authors analyse causes of the observed disparity. A high significance of the spatially correlated error term for the MDP indicator underlines the presence of an unaccounted external spatially correlated factor(s) affecting the MDP rate in the local municipalities. Evaluation of 2016 survey results about inhabitants' perceptions concerning current regional demographic changes and challenges provide further hints on the nature and complexity of the underlying undeclared migration processes. 